\title{
Artificial Persons and Attributed Actions: How to Interpret Action-Sentences about States
}

\begin{abstract}
Action-sentences about states, such as 'North Korea conducted a nuclear test', are ubiquitous in discourse about international relations. Although there has been a great deal of debate in IR about whether states are agents or actors, the question of how to interpret action-sentences about states has been treated as secondary or epiphenomenal. This article focuses on our practices of speaking and writing about the state rather than the ontology of the state. It uses Hobbes' theory of attributed action to develop a typology of action-sentences and to analyze action-sentences about states. These sentences are not shorthand for action-sentences about individuals, as proponents of the metaphorical interpretation suggest. Nor do they describe the actions of singular agents, as proponents of the literal interpretation suggest. The central argument is that actionsentences about states are 'attributive', much like sentences about principals who act vicariously through agents: they identify the 'owners' of actions - the entities that are responsible for them-rather than the agents that perform the actions. Our practice of ascribing actions to states is not merely figurative, but nor does it presuppose that states are corporate agents.
\end{abstract}

\section{Introduction}

Action-sentences about states are ubiquitous in discourse about international relations. Journalists report that 'North Korea conducted its fourth nuclear test' and that 'India has launched an unmanned model space shuttle' (Reuters, 2016; BBC, 2016). Waltz (1979: 109) declares that 'states have to do whatever they think necessary for their own preservation', and Finnemore (2003: 2) observes that ' [s]tates now intervene for reasons and in ways that were unimaginable one hundred or two hundred years ago'. We all use actionsentences about states, and, as Carr (1946: 149) suggested, '[i]t does not seem possible to discuss international relations in other terms'. But what exactly do we mean when we say that a state is acting, has acted, or will act? 
Although everyone intuitively understands sentences such as 'North Korea conducted a nuclear test' and 'India launched a space shuttle', these sentences remain deeply ambiguous. Are they literal or metaphorical? Do they describe the actions of corporate agents, or are they shorthand descriptions of the actions of human agents? What is their logical form? It is peculiar that the discipline of IR has devoted so little attention to one of its most common turns of phrase. The question of how to interpret action-sentences about states has been addressed only as an aside in the debate about whether states are agents or actors. $^{1}$ With few exceptions (Copp, 2006; Ludwig, 2007, 2014), even philosophers of action have neglected action-sentences about corporate entities.

The status of our discourse is of great importance. If action-sentences about states are metaphorical (e.g., Gilpin, 1984; Gould, 2009; Lomas, 2005, 2014; Marks, 2011), then they are dispensable. We would lose no explanatory power, and gain clarity and precision, by eliminating action-sentences about states in favour of action-sentences about human beings. 'North Korea conducted a nuclear test' is only figurative shorthand for 'some North Koreans conducted a nuclear test'. However, if action-sentences about states are literal (e.g., Erskine, 2001; Wendt, 1999, 2004, 2005), then they are indispensable. We would lose explanatory power but gain nothing if we eliminated them. 'North Korea conducted a nuclear test' can be expressed in terms of individuals no more than 'Beethoven conducted the Ninth Symphony' can be expressed in terms of cells; 'North Korea', like 'Beethoven', is a singular subject that performs a singular action. At stake is whether our common descriptions and explanations are necessary or whether they are merely placeholders that could be supplanted by more precise descriptions and explanations. 
Behind the semantic disagreement about how to interpret actionsentences about states lies an ontological disagreement about the nature of collective action. While the metaphorical interpretation follows from the ontological position that only individuals are capable of acting, the literal interpretation follows from the ontological position that states are agents in their own right. Proponents of each interpretation employ the same structure of argument: they use ontological claims about collective action to justify semantic claims about what our common language means. The existing debate about how to interpret action-sentences about states is entirely parasitic on the debate about the ontological status of the state.

I propose both a different approach and a different answer to the question of how to interpret action-sentences about states. First, on pragmatic grounds, I give priority to language over ontology. Instead of developing an ontology of the state and then using it to determine how to interpret action-sentences about states, I begin with our practice of ascribing actions to states and ask which ontological commitments this practice entails. Second, following this methodological prescription, I use Hobbes' theory of attributed action to develop an alternative to the metaphorical and literal interpretations. According to this 'attributive' interpretation, action-sentences about states are more like sentences about principals who act vicariously through agents than like tropes or like sentences about singular agents. These sentences identify states as the 'owners' of actions-the entities that are responsible for them-rather than the agents that perform the actions. Just as we say 'Jane bought a house' when an estate agent buys a house in her name, we say 'North Korea conducted a nuclear test' when the authorized representatives of the state conduct a nuclear test in 
its name. We attribute the nuclear test to North Korea not because North Korea is the agent that conducted it, but because North Korea is responsible for it. I argue that the attributive interpretation best captures what we commonly mean when we use action-sentences about states. Our practice of ascribing actions to states is not merely figurative, but nor does it commit us to the state-as-agent thesis.

The article has four sections. In the first section, I reconstruct the argument for the metaphorical interpretation. I show that it fails on its own terms because action-sentences about states are not logically equivalent to action-sentences about individuals. In the second section, I reconstruct the argument for the literal interpretation. The drawback of the literal interpretation is that it depends on the contentious idea that states are agents. In the third section, I explain how a pragmatic focus on language allows us to sidestep the protracted debate about the ontological status of the state. Although we may never settle the issue of whether states are agents, we can settle the more limited issue of which ontological commitments our discourse entails. In the fourth section, I develop the attributive interpretation. I present a typology of actionsentences, and I show that many are neither 'agentive', like 'Jane chastised him', nor 'figurative', like 'Jane tore a strip off him'. Action-sentences about states are 'responsibility attributive': they identify states as the owners of actions, not as agents or as subjects of tropes. I conclude that although the attributive interpretation best captures the meaning of our language about the state, it is historically specific. It may or may not apply to other languages, societies, times, or types of collective entities. 


\section{The metaphorical interpretation}

Proponents of the metaphorical interpretation use the ontological claim that only human beings can act to justify the semantic claim that actionsentences about states are shorthand for action-sentences about individuals. Because states cannot literally act, 'North Korea conducted a nuclear test' must really mean something like 'some North Koreans conducted a nuclear test'. The surface grammar of action-sentences about states masks their true logical form. The state 'is a "they" rather than an "it"' (Shepsle, 1992).

Gilpin (1984) provides the classic argument for the metaphorical interpretation in IR. He argues that 'the state does not really exist', let alone act: 'Only individuals act, even though they may act on behalf of one of these collective social entities' (301). Although Gilpin concedes that 'we (all of us, including critics of "neorealists") do write as if some particular social or political entity really does exist and acts' (301), he argues that it is only 'a matter of convenience and economy to do so'. Action-sentences about states ought to be interpreted as shorthand: 'we speak of the Soviets doing such-and-such rather than listing the individual members of the Central Committee who in reality did the acting' (301). Gilpin warns that there is 'a danger in this practice of coming to think of the state as an actor in its own right' and promises to be more careful with his language from then on (301). ${ }^{2}$

Lomas $(2005,2014)$ and Marks (2011) provide the most recent arguments for the metaphorical interpretation. Lomas (2014: vii-viii) takes aim at 'the conventional wisdom of international relations, of treating states as agents - that is, able to take action-in their own right', which 'has no basis in reality or common sense'. His ontological claim that states cannot act underpins 
his semantic claim that 'it is never right to speak of states acting' and that the common tendency to do so is 'a misleading habit' (2005: 355n, emphasis in original; 2014: 39, 71-74). Lomas argues that action-sentences about states are pernicious metaphors that can and ought to be eliminated from our discourse: 'Scientists induce chemical changes; bus drivers drive buses; governments govern us. States do nothing. We have no need of a verb for them' (2014: 39). Marks (2011: 16) agrees with Lomas that ascribing actions to states is a metaphor, but he sees it as a benign one: 'the metaphor [of state agency] is useful since it would be much easier to simply write "France" instead of "French foreign policymakers"'. What unites proponents of the metaphorical interpretation is the belief that action-sentences about states are figurative shorthand for actionsentences about individuals.

If action-sentences about states are shorthand, then it should be possible to spell out the longhand. The test for the metaphorical interpretation is whether action-sentences about states can be translated into logically equivalent actionsentences about individuals (Copp, 2006: 200-4). The key here is logical equivalence: the truth-value of the longhand sentence must co-vary with the truth-value of the shorthand sentence. If it is possible for one sentence to be true while the other is false, then the two sentences are not logically equivalent (Lover, 2008: 153-64; Yaqub, 2013: 19-20), so we can infer that one sentence cannot be shorthand for the other. For example, 'Margaret Thatcher signed the Anglo-Irish Agreement' is logically equivalent to 'the Iron Lady signed the AngloIrish Agreement' because there is no possible scenario in which Margaret Thatcher signed the Agreement but the Iron Lady did not; 'the Iron Lady' is another name for Margaret Thatcher. However, 'Margaret Thatcher signed the 
Anglo-Irish Agreement' is not logically equivalent to 'the prime minister signed the Anglo-Irish Agreement', since it is possible for one sentence to be true while the other is false. If someone else had been prime minister at the time, then it might still be true that the prime minister signed the Anglo-Irish Agreement, but it would be false that Margaret Thatcher signed it. The test for the metaphorical interpretation is thus whether sentences such as 'North Korea conducted a nuclear test' are logically equivalent to action-sentences about individuals.

The logical equivalence test sets a low standard for the metaphorical interpretation, since sentences can be logically equivalent without being equivalent in meaning (Cruse, 1986: 98-99). Although 'Margaret Thatcher signed the Anglo-Irish Agreement' and 'the Iron Lady signed the Anglo-Irish Agreement' have covariant truth-values, they do not have the same 'cognitive significance' (Chalmers, 2002). Someone may know that Margaret Thatcher signed the Agreement but not that the Iron Lady did. The metaphorical interpretation might be construed as the stronger claim that action-sentences about states are equivalent in meaning to action-sentences about individuals (Wendt, 1999: 197), but I focus on logical equivalence to give the metaphorical interpretation the benefit of the doubt.

The simplest version of the metaphorical interpretation equates actionsentences about states with action-sentences about particular individuals. As Gilpin (1984: 301) argues, we ascribe actions to the state 'rather than listing the individual members of the [state] who in reality did the acting'. We might say that 'France conducted airstrikes' is shorthand for an action-sentence about the particular French pilots-say, Jean and Pierre-who flew the planes and dropped the bombs. 'France conducted airstrikes' could be paraphrased as 'Jean 
and Pierre conducted airstrikes', and the reference to the state could be eliminated. The problem with this translation is that it cannot account for counterfactuals about what would have happened if different members of the state had acted or if the membership of the state had been different (Sheehy, 2006: 17-23). If different French pilots, Lucien and Jacques, had conducted the airstrikes, then 'France conducted airstrikes' would remain true but 'Jean and Pierre conducted airstrikes' would be false. The fact that the truth-values of the two sentences can vary independently shows that they are not logically equivalent. We would say 'France conducted airstrikes' even if we had no idea which French pilots conducted the airstrikes. The truth-value of the sentence about France is indifferent to which particular individuals perform the action, so the sentence cannot be shorthand for a sentence about particular individuals. Ludwig (2014) and Marks (2011) argue that action-sentences about states are equivalent to action-sentences about individuals qua state officials rather than individuals qua individuals. The name of the state stands in for an adjective-nationality—and the individual agents are identified according to their roles instead of their individual identities. For instance, 'France conducted airstrikes' is short for 'French military personnel conducted airstrikes'. The advantage of this translation over Gilpin's is that it can accommodate many counterfactuals. 'French military personnel conducted airstrikes' remains true no matter which particular individuals conducted the airstrikes. However, this translation still falls prey to counterexamples. If the French military personnel who conducted the airstrikes had gone rogue and attacked other NATO members, then 'French military personnel conducted airstrikes' would be true but 'France conducted airstrikes' would be false. We would not say, in this case, 
that France conducted airstrikes against its own allies. Similarly, if some British

soldiers shot at their own barracks, we would not say 'Britain shot at its

barracks'; we would ascribe the shooting only to those particular soldiers.

Action-sentences about states are not equivalent to action-sentences about state officials or a subset thereof, since, in many circumstances, we do not treat the actions of state officials as acts of state. As I argue below, what is missing from the metaphorical interpretation is the idea that individuals act in the name of the state.

In sum, the metaphorical interpretation appeals to our common sense but fails to make sense of our common language. As its proponents rightly point out, states are often said to act, but they never seem to do anything. Particular soldiers cross the border whenever one state 'invades' another, and a particular person writes her name on the page whenever a state 'signs' a treaty. Mysteriously, however, action-sentences about states defy our attempts to paraphrase them away.

\section{The literal interpretation}

The literal interpretation is the mirror image of the metaphorical interpretation. Its proponents use the ontological claim that states are corporate agents to justify the semantic claim that action-sentences about states are parallel in meaning and logical form to action-sentences about human beings. 'France conducted airstrikes', like 'Patrick conducted traffic', ascribes a singular action to a singular agent.

Wendt $(1999,2004,2005)$ is the main proponent of the literal interpretation in IR. He notes that citizens, policymakers, journalists, and 
scholars all ascribe actions to states: 'We think the United States has "security interests" in the Persian Gulf, that it "believed" those were threatened by Iraq's "conquest" of Kuwait, that as a result it "attacked" Iraq, that its actions were "rational" and "legitimate", and so on' (1999: 195; 2004: 289). If 'state personhood is a "long discredited" idea', he writes in response to Lomas (2005), 'it is certainly strange that it continues to appear so often in our discourse' (Wendt, 2005: 357). ${ }^{3}$ It is stranger still that action-sentences about states appear so often in the discourse of people who deny that states are agents. Wendt argues that these sentences ought to be interpreted literally on the grounds that 'states are people too' - that is, 'states are real actors to which we can legitimately attribute anthropomorphic qualities like desires, beliefs, and intentionality' (1999: 197; 2004).

Wendt draws support from the philosophy of action, where the literal interpretation has become common. List and Pettit (2011: 4-5) argue that 'talk of group agents cannot be dispensed with in favor of talk about individual agents'. Copp (2006: 195) points out that 'Britain intentionally sank the Belgrano' is parallel in form to 'Margaret Thatcher intentionally sank her dinghy', and he suggests that the two sentences should be interpreted in the same way: 'It would be natural to take these and similar claims to entail or to presuppose the propositions that states such as Britain and Argentina ... are capable of making plans and of performing actions intentionally in executing their plans'. The justification for interpreting action-sentences about states literally is that states are literally agents, just as individuals are literally agents.

The most influential argument for corporate agency is the 'supervenience' argument, which uses judgment aggregation theory to explain how it is possible 
for groups to have intentions (List and Pettit, 2006, 2011). There are two findings from judgment aggregation theory that support the idea of corporate agency. First, groups with certain voting procedures can have intentions that none of their members have. For example, Tollefsen (2015: 60-62) describes a scenario in which a three-member admissions committee evaluates $\mathrm{PhD}$ applicants in four areas: test scores, grades, letters of recommendation, and writing samples. Only applicants who excel in all four areas may be admitted, and whether a candidate excels in a given area will be determined by a majority vote. The committee members vote as follows on Patrick's application.

TABLE 1. Tollefsen's admissions committee

\begin{tabular}{|l|c|c|c|c|c|}
\hline & $\begin{array}{c}\text { Good test } \\
\text { score? }\end{array}$ & $\begin{array}{c}\text { Good } \\
\text { grades? }\end{array}$ & $\begin{array}{c}\text { Good } \\
\text { letters? }\end{array}$ & $\begin{array}{c}\text { Good writing } \\
\text { sample? }\end{array}$ & $\begin{array}{c}\text { Accept the } \\
\text { candidate? }\end{array}$ \\
\hline Member \#1 & Yes & No & Yes & No & No \\
\hline Member \#2 & No & Yes & Yes & Yes & No \\
\hline Member \#3 & Yes & Yes & No & Yes & No \\
\hline Committee & Yes & Yes & Yes & Yes & Yes \\
\hline
\end{tabular}

(Tollefsen, 2015: 61)

Although none of the committee members believe that Patrick excels in every area, the majority of them believe that he excels in every area. As a result, when the votes are tallied, the committee decides to admit Patrick to the PhD program even though none of its members think he meets the criteria for admission. 'We intend to admit Patrick to the program' is true even though 'I intend to admit Patrick' is false for each committee member. Further, even in more typical cases, the intentions of a committee are not simple sums of the intentions of its members. Collective intentions are 'multiply realizable', which means that the same collective intention can be brought about by different combinations of individual intentions (List and Pettit, 2011: 65-66; Tollefsen, 2015: 87-88). The committee might still have decided to admit Patrick if each of its members had 
voted differently, and even if the committee had entirely different members. The intentions of the committee 'supervene' on the intentions of its members, which means that the former are dependent on but not reducible to the latter. List and Pettit (2011: 78) conclude that, in order to make sense of these findings, 'we must think of group agents as relatively autonomous entities-agents in their own right, as it is often said'. The supervenience argument is especially powerful because it begins from individualist premises; it implies that corporate agents are not reducible to individual agents even though they are entirely made up of individual agents.

Wendt (1999: 217; 2004: 300-1; 2005: 358) applies the supervenience argument to the state: 'even though the intentions of a state person at any given moment are ontologically dependent on its constituent members, its intentions are not dependent on any particular members' (2004: 300, emphasis in original). A state's intention to wage war can be realized by different legislators just as a committee's intention to admit an applicant can be realized by different members. Wendt (2004: 305) points out that the state-as-agent thesis does not require collective consciousness, since 'the weak, supervenience variant [of corporate agency] alone justifies a realist view of state persons'. Pettit (2014: 1642) agrees that states-but only 'well-functioning' states that are capable of unified decision-making and action—count as corporate agents.

Wendt (2015: 247-66) repudiates the supervenience argument in his latest work on quantum social science. Instead, he takes the much stronger position that states are conscious agents. His first move is to embrace 'enactivism' in the philosophy of mind, which holds that 'consciousness is a transaction between the mind and its environment' (277); it is not simply a 
function of the brain. An enactivist would say that, in the process of reading this article online, the Internet is as much a part of the relevant conscious system as is the reader's brain. Wendt's second move is to employ the concept of 'Wefeeling', or the idea that groups have shared points of view akin to first-person perspectives (277-78). Some experiences, such as national pride, are irreducibly collective. This is not to say that the group's experience exists at a higher 'level', but that, through quantum entanglement, each individual's experience of national pride is inextricable from the experiences of other members of the group. If consciousness is not entirely a function of individual brains, and if groups are capable of having subjective experiences, then it is a short step to considering states to be conscious agents as well as intentional agents.

The virtue of the literal interpretation-supervenience or quantum-is that it accords well with the ways that we commonly speak and write about the state. Unlike the metaphorical interpretation, it does not require individualistic paraphrases, so the issue of logical equivalence does not arise. 'France conducted airstrikes' can simply be taken at face value.

The problem with the literal interpretation is that it rests on contested ontological ground. Far from being 'one thing on which almost all of us agree' (Wendt, 2004: 289), the state-as-agent thesis remains contentious. Wight (2006: 188) argues that 'Wendt's theory of the state rests on the classic error of methodological structuralism: the attribution of the agential powers and attributes of human agents to a collective social form'. Franke and Roos (2010) accuse Wendt of blurring his own distinction between agents and structures. Kustermans (2011) objects to Wendt's equation of 'person' and 'actor', and he argues that states are moral and legal persons even though they are not actors. 
Keeley (2007: 10) describes Wendt's argument for quantum consciousness as 'one contested statement piled on top of another'. On one hand, most participants in the state-as-agent debate reject the state-as-agent thesis (Franke and Roos, 2010; Kustermans, 2011; Lomas, 2005, 2014; Neumann, 2004; Wight, $1999,2004,2006)$. On the other hand, many international political theorists consider the state to be a moral agent (Erskine, 2001; Lang, 2007; Pasternak, 2013; Stilz, 2011; Valentini, 2011). It seems unlikely that the state-as-agent debate will ever be decisively settled. A simple question about our everyday language-how should we interpret action-sentences about states?-has drawn us into an ontological quagmire.

\section{Language over ontology}

One way to move beyond the protracted state-as-agent debate is to reverse the priority of ontology over language. Instead of starting with the ontology of the state, we should start with our practice of ascribing actions to states. Giving priority to language over ontology is obvious to many on the critical side of IR scholarship, who argue that the state does not exist independently of practices, including our practices of speaking and writing about it (Jackson, 2004b; Neumann, 2004; Ringmar, 1996; Schiff, 2008). Using ontological arguments to justify interpretations of language is backward because language does not simply reflect reality; it helps to construct reality. As Schiff (2008: 371) argues, 'the state is real for us precisely because we think and speak and act as if it is'. Further, as Neumann (2004: 265) argues, the literal/metaphorical dichotomy that frames much of the state-as-agent debate is a false one: 'If one believes, as I do, that thinking depends on the language in 
which it is couched, and that language cannot help but be metaphorical, then the key question is not whether a certain phenomenon is metaphorical or not, but which metaphors constitute it, with what effects'. The question is not whether action-sentences about states are literal or metaphorical, but what the implications of using these action-sentences are. These critical interventions in the state-as-agent debate have helped to rein in the speculative 'ontologism' of both sides.

Even if we do not believe that social reality is constituted by language or that all language is metaphorical, there is a pragmatic reason to begin with language rather than ontology. We may always disagree about 'what there is', but, as Quine (1948) argues, we can still reach some agreement about what particular forms of discourse presuppose. Instead of developing an ontology of the state and then interpreting action-sentences about states accordingly, we should begin with the language that we use and ask which ontological commitments it entails. Proponents of the literal and metaphorical interpretations ask, 'given that states are (not) agents, how must we interpret action-sentences about states?' I ask a much more modest but tractable question: 'given that we all use action-sentences about states, what are we ontologically committed to?' The aim here is to uncover the presuppositions of our common language, not the fundamental nature of reality.

I begin with the basic observation that everyone who speaks or writes about international relations, from citizens to policymakers to scholars, uses and understands action-sentences about states. Whether or not we believe that states are agents, we all understand 'North Korea conducted a nuclear test' and 'Syria deployed chemical weapons'. Action-sentences about states are ubiquitous, 
intelligible, and fundamental to the theoretical language of IR; they are surely not nonsense.

Another important point is that we could not eliminate action-sentences about states in favour of action-sentences about individuals, even if we wanted to. If these sentences were merely figures of speech, then we could produce logically equivalent paraphrases to show that we are not committed to the stateas-agent thesis. I have argued in the first section that proponents of the metaphorical interpretation have tried and failed to do this. We cannot translate action-sentences about states into logically equivalent action-sentences about individuals, so we cannot avoid ontological commitments simply by dismissing our practice of ascribing actions to states as a trope.

We seem to be led back to the literal interpretation. If states were not agents, then how could we ascribe actions to them? Our use of action-sentences about states commits us to the state-as-agent thesis unless we can provide an alternative interpretation that accords as well or better with our common language.

\section{Back to Hobbes: The attributive interpretation}

Jackson (2004b) suggests a promising alternative to the literal interpretation, which is, in part, to return to Hobbes' understanding of action.

When we study social actors, we should be attuned to the concrete processes which accomplish the bounding of those actors; in particular, we should pay attention to what Hobbes called 'personation': the social process by which someone is empowered to speak on behalf of (or 'in the 
name of') an entity, thereby making that entity an actor. (286-87, emphasis in original)

Jackson argues that states are persons because social practices constitute them as persons, not because they have metaphysical essences that make them persons. The same is true of individuals. He uses the example of women, who are socially empowered to act in some societies but were (and still are) denied personhood in many other societies (286). Women and states are persons because we ascribe actions to them; it is not that we can ascribe actions to them only because they have some pre-social features of personhood. Turning the literal interpretation on its head, Jackson declares that 'people are states too', by which he means that the personhood of individuals is no less socially constituted than is the personhood of the states.

Jackson deliberately elides Hobbes' distinctions between different types of persons in order to emphasize the point that persons are socially constituted 'all the way down'. But even if we agree with this point, there are good reasons to make these distinctions, since not all persons are socially constituted in the same way. Women and states are certainly not persons of the same kind. Hobbes' theory of attributed action captures the intuitive difference between the kind of personation involved in 'Jane bought a house' and the kind involved in 'France bought a house'.

\section{A Hobbesian typology of persons and action-sentences}

Hobbes defines a person as 'he that is Represented' or 'he to whom the actions of men are attributed' (2012: 776; 1991: 83, emphasis in original). To 'personate' someone is to represent her or to act in her name. While a 'natural 
person' acts in her own name, an 'artificiall person' acts vicariously through someone else (1991: 83; 2012: 244). ${ }^{4}$ Jane is a natural person when she buys a house on her own, but she is an artificial person when her estate agent buys a house in her name. A peculiar feature of our language is that we often describe the actions of natural and artificial persons in the same way. We say 'Jane bought a house' regardless of whether she or her estate agent 'performed' the action of buying it. If she is a natural person, then the sentence is 'agentive': it identifies Jane as the agent who bought the house. But if she is an artificial person, then the sentence is 'attributive': it identifies Jane as the owner of the action, or the person who is responsible for buying the house. Although her estate agent made the deal with the seller and carried out the transaction, we nevertheless attribute the purchase to Jane; we consider the action to be hers. She is bound by the deal and must pay for the house no less than if she had bought it on her own. Artificial persons and attributed actions are commonplace in modern social and political life. People often buy and sell things, make investments, submit tax returns, file lawsuits, and even vote through agents who perform these actions in their names.

Artificial persons can be represented either 'Truly or by Fiction' (Hobbes, 2012: 244, emphasis in original). While a true artificial person acts vicariously through an agent that she has authorized, a fictional artificial person acts vicariously through an agent that someone else has authorized. Jane is a true artificial person if she hires an estate agent to buy a house in her name; she is both the author and the owner of the purchase. Jane is a fictional artificial person if someone else hires an estate agent to buy a house in her name. Under normal circumstances, an estate agent cannot act in Jane's name unless she has 
authorized him. However, if Jane were a young child with a large inheritance, her guardian might authorize an estate agent to buy a house in her name-for instance, as a wise investment for the future. The purchase is attributed to Jane, and her money pays for the house, even though her guardian is the author of the purchase. The meaning of 'Jane bought a house' thus depends on which type of artificial person Jane is. If she is a true artificial person, then the sentence is 'authority attributive': it identifies Jane as the owner of the purchase as well as the author who commissioned it. If she is a fictional artificial person, then the sentence is 'responsibility attributive': it identifies Jane as the owner but not the author. ${ }^{5}$ Fictional personation is most common when people require representation but 'can be no Authors' because they 'have no use of Reason' (Hobbes, 2012: 248). It occurs when guardians act in the names of children, lawyers represent incompetent defendants, and family members make decisions for severely ill relatives.

Fictional artificial persons need not even be human: 'Inanimate things, as a Church, an Hospital, a Bridge, may be Personated by a Rector, Master, or Overseer' (Hobbes, 2012: 246; 1991: 85). Although 'things Inanimate cannot be Authors, nor therefore give Authority to their Actors: Yet the Actors may have Authority to procure their maintenance, given them by those that are Owners, or Governours of those things' (2012: 246). For example, when an employee of a hospital buys an x-ray machine in the name of the hospital, the purchase can be attributed to the hospital. We say 'St. Clare's Hospital bought an x-ray machine' even though the employee performed the action of buying the machine and the director of the hospital authorized her to do so. The employee is the agent, the director is the author, but the hospital is the owner. Even '[a]n Idol, or meer 
Figment of the brain, may be Personated', as were 'the Gods of the Heathen' in Ancient Rome (2012: 246). Although 'idols cannot be Authors: for an Idol is nothing', the Romans authorized representatives to act in the name of the gods (2012: 246). They might have said 'Jupiter bought a temple' for the same reason that we would say 'St. Clare's Hospital bought an x-ray machine'. Hobbes' point is that we can attribute actions to anything that has an authorized representative, even if it is not an agent or an author (Skinner, 1999: 13-18). Action-sentences about infants, inanimate objects, and imaginary entities are all responsibility attributive: they identify the owners of actions rather than the agents or authors.

The claim that churches, hospitals, bridges, and idols can be persons falls strangely on modern ears, in large part because Hobbes' usage of 'person' differs from contemporary philosophical and political usages. Whereas modern philosophers and IR scholars tend to use 'person' to mean 'intentional and/or rational agent', Hobbes uses 'person' to mean 'entity to which actions are attributed in speech or writing'. Hobbesian persons, unlike Wendtian persons, are products of language rather than pre-social entities. As Pettit (2008: 55) puts it, 'persons are distinguished not by their metaphysical nature but by the things they can do, the roles they can play'.

Which roles an entity can play, and thus what kind of person it is (if any), varies across times, places, and circumstances. Hobbesian personhood is not a fixed status. For example, women in many contemporary societies are natural persons, since they are considered to speak and act for themselves. However, in some paternal societies, women were only fictional artificial persons because they were considered to act only through their male family members. Although almost all women throughout history were agents — that is, intentional or 
purposive systems (e.g., List and Pettit, 2011: Ch. 1; Wendt, 2004: 295; Wight, 2006: 211-12)—many were denied personhood entirely. Conversely, although the Sun is not an agent, it has often been a person, since many societies throughout history have attributed actions to it. Agents need not be persons, and persons need not be agents. I use 'agency' to denote the capacity for intentional action and reserve 'personhood' to denote the social status of being a subject of action-sentences.

The types of Hobbesian persons correspond to different modes of attribution. Natural personation is a reflexive relation of attribution in which an entity is considered to act for itself, as in 'Jane bought a house [in her own name]'. True artificial personation is a dyadic relation of attribution in which one entity is considered to act through another, as in 'Jane bought a house [through an estate agent whom she authorized]'. Fictional artificial personation is a triadic relation of attribution in which one entity is considered to act through another entity that is authorized by a third, as in 'Jane bought a house [through an estate agent whom her guardian authorized]'. It bears repeating that personhood is socially determined, not essential or immutable. Which type of person Jane is at a given time depends on whether the relevant audience considers her to act for herself, through another whom she has authorized, or through another whom a third party has authorized.

In sum, although all action-sentences have the same basic grammatical form, action-sentences about different types of persons identify different types of subjects. 
TABLE 2. A Hobbesian typology of action-sentences

\begin{tabular}{|c|c|c|}
\hline Type of Person & Type of Action-Sentence & Type of Subject \\
\hline Natural & Agentive & Agent \\
\hline True artificial & Authority attributive & Author \\
\hline Fictional artificial & Responsibility attributive & Owner \\
\hline
\end{tabular}

Action-sentences about natural persons, such as 'Jane bought a house [in her own name]', are agentive: the subject is the agent who performed the action. Action-sentences about true artificial persons, such as 'Jane bought a house [though an estate agent whom she authorized]', are authority attributive: the subject is the author who commissioned the action. Action-sentences about fictional artificial persons, such as 'Jane bought a house [though an estate agent whom her guardian authorized]' or 'St. Clare's Hospital bought an x-ray machine', are ownership attributive: the subject is the owner who is considered to be responsible for the action. The same sentence-'Jane bought a house'-can vary in meaning depending on which type of person we take Jane to be at a given time.

Different types of action-sentences come with different ontological commitments. Agentive sentences entail that their subjects are agents, or intentional systems, since an entity must have intentionality in order to perform actions. What distinguishes actions from other behaviour is that they are intentional, or that they are guided by representations such as desires and beliefs (List and Pettit, 2011: 19-31). 'The Sun bought a temple [in its own name]' thus presupposes that the Sun is an agent. If this sentence seems absurd, it is because we deny its presupposition of agency. The sentence would be perfectly sensible in a society in which the Sun is considered to be an anthropomorphic deity instead of an inanimate sphere of hot plasma. Authority attributive sentences also entail that their subjects are agents, since an entity could not 
authorize its own representative unless it could perform actions. 'The Sun bought a temple [through a representative whom it authorized]' likewise presupposes that the Sun is an agent. However, responsibility attributive sentences do not entail that their subjects are agents. The Sun need not be an agent in order for 'the Sun bought a temple [through a representative whom its guardian authorized]' to be true; the sentence assumes only that the Sun's guardian and representative are agents. As long as its guardian and representative perform the relevant actions in its name, the Sun can buy a temple without ever performing an action. We can therefore use responsibility attributive sentences about the Sun without contradicting the belief that the Sun is not an agent. While agentive and authority attributive sentences both entail that their subjects are agents, responsibility attributive sentences do not.

\section{What type(s) of persons are states?}

How we interpret action-sentences about states depends on what type or types of persons we take states to be. There are four possibilities. The first option is to treat states as metaphorical persons, which implies that action-sentences about states are figurative. I have already argued that there are compelling reasons to reject this position. The second option is to follow Wendt $(1999,2004$, 2005) and treat states as natural persons. According to his view, actionsentences about states are agentive; 'France bought a house' identifies France as the agent who performed the action of buying a house. The third option, which Copp $(1979,2006)$ proposes, is to treat states as true artificial persons:

The relation between a collective and the individual agents whose actions constitute its action is akin to the relation between a principal and an 
authorized agent, as obtains, for example, when my attorney signs some papers with the upshot that I purchase some property. (2006: 205) According to Copp, action-sentences about states are authority attributive; 'France bought a house' identifies France as the author who commissioned the purchase of a house. Copp's interpretation might be considered a variant of the literal interpretation because it presupposes the state-as-agent thesis no less than Wendt's interpretation does. If states could not perform actions, then they could not be true artificial persons, since they would not be able to authorize their own representatives. It is difficult to see how an entity could be an author if it were not an agent.

Hobbes rejects all three of these options. He argues that states cannot be natural persons because they cannot act in their own names: 'the Commonwealth is no Person, nor has capacity to doe any thing, but by the Representative' (Hobbes, 2012: 416). France cannot sign a treaty unless at least one of its officials signs her name on the page. Nor can states be true artificial persons, since they cannot authorize their own representatives (2012: 260, 262). France cannot elect a president unless some of its citizens vote for him. Least of all are states metaphorical persons, since they truly own the actions of their authorized representatives. There is nothing metaphorical about France's debts and treaty obligations. Hobbes considers states to be fictional artificial persons (Runciman, 2000; Skinner, 2007), much like hospitals and Roman gods:

A Multitude of men, are made One Person, when they are by one man, or one Person, Represented ... And because the Multitude naturally is not One, but Many; they cannot be understood for one; but many Authors, of 
every thing their Representative saith, or doth in their name (2012: 24850)

The individual members of the state authorize representatives, these representatives act in the name of the state, and we therefore attribute their actions to the state (Runciman, 2009). In other words, the members of the state are the authors, state officials are the agents, but the state is the owner.

Action-sentences about states, as we commonly use them, are responsibility attributive. We say 'France bought a house' not because France performed the action of buying a house, nor because France authorized an agent to buy a house in its name, but because France is responsible for buying a house. We attribute the purchase to France, and it is paid for using public funds, even though state officials performed it and the members of the state authorized it. Likewise, we say 'North Korea conducted a nuclear test' because North Korea is responsible for the nuclear test. Although particular North Koreans carried out the nuclear test, we attribute their actions to North Korea because they were authorized to act in the name of the state. The condemnation and sanctions that follow these nuclear tests is accordingly targeted at North Korea. When we attribute an action to a state, what we ordinarily mean is that (1) some human beings performed the action; (2) they acted in the name of the state; (3) they were authorized to do so; and (4) therefore, the state is responsible for the action.

First, an action-sentence about a state is true only if some people have acted accordingly. 'France bought a house' implies 'some people bought a house'. This condition also holds for complex collective actions, which can be ascribed to the state but not to any individual (French, 1984: 5; Erskine, 2001: 27). 'North 
Korea conducted a nuclear test' implies 'some people conducted a nuclear test', even though none of these people could have conducted the nuclear test on their own. In this case, the action of the state is 'constituted' by the actions of many individuals-designing the rocket, assembling the warhead, planning the launch, and so on (Copp, 2006: 205). Even proponents of the literal interpretation take it to be obvious that '[g]roups are composed of individuals and they act via the actions of individuals' (Tollefsen, 2015: 4; List and Pettit, 2011: 64).

Second, an action-sentence about a state is true only if the people who performed the action did so in the name of the state. When British soldiers shoot at Islamic State training camps, we attribute their actions to the United Kingdom because they represent the state. However, when British soldiers deliberately shoot at their own barracks, they no longer represent the state. Their actions are attributable to them as individuals. We would not say 'Britain shot at its own barracks', as Ludwig's (2014) interpretation implies; we would say ‘some rogue British soldiers shot at Britain's barracks'. What distinguishes an act of state is that it is performed in the name of the state.

Third, an action-sentence about a state is true only if the people who performed the action had the requisite authority. The kind of authority at issue here is not the formal or legal right to act in the name of the state, but the socially ascribed status of state agent. Although Russia has not formally authorized the pro-Russian rebels in Eastern Ukraine, we might nevertheless consider the rebels to be authorized agents of Russia because Russia supports and arms them. However, when people act in the name of a state but have not been authorized, we do not attribute their actions to the state. As Hobbes (2012: 378) puts it, 'a Souldier without Command, though he fight for the Common-wealth, does not 
therefore represent the Person of it'. Members of the Irish Republican Army (IRA) acted in the name of the Republic of Ireland, but, because they were not authorized to do so, their actions were not attributable to the state. We say that the IRA assassinated Lord Mountbatten, not that the Republic of Ireland did. The concept of authority thus distinguishes personation of the state from impersonation of the state.

When individuals act in the name of the state and with the requisite authority, the state is the owner of their actions, which means that the state is responsible for them. This responsibility can be causal, normative, or both. In some cases, we attribute an action to a state to indicate that the state caused it, as in 'Russia blocked the Security Council resolution'. In other cases, we attribute an action to a state to indicate that the state is morally or legally responsible for it, as in 'Greece owes billions of Euros to its creditors'. Many action-sentences about states imply both causal and normative responsibility. We say 'North Korea conducted a nuclear test' both because North Korea caused the nuclear test and because North Korea is culpable for it. The people who conducted the nuclear test would not have done so, nor even been able to do so, if not for the structure of the state, and the state is censured for the nuclear test. The core idea of the attributive interpretation is that action-sentences about states express claims of responsibility, not of authorization or agency.

\section{Implications and objections}

The attributive interpretation reconciles the opposing intuitions that animate the literal and metaphorical interpretations—-that action-sentences about states are something more than figures of speech, but that they are also 
fundamentally different from action-sentences about individuals. It avoids both the anthropomorphism of the literal interpretation and the reductionism of the metaphorical interpretation.

Unlike the literal interpretation, as well as Jackson's (2004b) inversion of it, the attributive interpretation captures the differences between actionsentences about states and those about individual agents and principals. Although 'Jane bought a house [in her own name]' and 'Jane bought a house [through an estate agent whom she authorized]' are both grammatically identical to 'France bought a house', the three sentences differ in kind. The first sentence identifies an agent who purchased a house; the second identifies an author who commissioned the purchase of a house; and the third identifies an owner who is responsible for the purchase of a house. 'France bought a house' is more akin to 'Jupiter bought a temple' than it is to either form of 'Jane bought a house'. People tend to resist the literal interpretation perhaps because they intuitively recognize the differences between natural, true artificial, and fictional artificial persons.

How we categorize action-sentences matters greatly when it comes to assigning responsibility. The ethical and legal consequences of 'Jane failed to follow the safety procedures'-for instance, whether Jane faces a fine or prison time, and which defences are available to her-depend in large part on whether we consider Jane to be the agent, author, or owner of the action. If the sentence is agentive, then Jane may be charged with criminal negligence. She might defend herself by arguing that she intended to follow the safety procedures but was unable to do so. If the sentence is authority attributive, then Jane may instead be sued for negligence. In this case, the responsibility in question is vicarious or 
civil, and whether Jane intended to follow the safety procedures is much less important. What matters is whether Jane authorized the agent who failed to follow the safety procedures. If the sentence is responsibility attributive, then Jane may still face civil rather than criminal responsibility, but the relevant considerations are different again. What matters is who counts as Jane's guardian, what authority this guardian has, and whether this guardian authorized the agent who failed to follow the safety procedures. While agentive action-sentences raise questions of criminality and intentionality, attributive action-sentences raise questions of civil liability, authorization, and representation.

The international law of responsibility relies implicitly on the distinction between agentive and attributive action-sentences. A significant feature of this body of law is that states, unlike individuals, cannot be held criminally responsible. The Nuremberg Tribunal's (1947 [1946]: 221) declaration that '[c]rimes against international law are committed by men, not by abstract entities' remains the rule (Crawford, 2013: 53). The reason that international lawyers assign criminal responsibility to individuals but not to states is that they consider the actions of individuals and states to be different in kind. Unlike an individual, 'the State cannot act of itself ... The question is which persons should be considered as acting on behalf of the State, i.e. what constitutes an "act of the State" for the purposes of State responsibility' (ILC, 2001: 35; see also Cassese, 2001: 35; Condorelli and Kress, 2010: 221; Nollkaemper, 2003: 616). In other words, while individuals can be natural persons, states can only be artificial persons-and perhaps only fictional artificial persons. An important consequence of this distinction is that 'Jean-Paul committed genocide' and 
'Rwanda committed genocide' involve different kinds of responsibility. While Jean-Paul can be held criminally responsible for genocide, Rwanda's responsibility is more akin to vicarious or civil responsibility. Jean-Paul faces imprisonment; Rwanda has obligations to compensate victims, to promote reconciliation, and to reform the structures that permitted the genocide. The attributive interpretation thus explains the longstanding legal practice of assigning different kinds of responsibility to individuals and states.

The attributive interpretation also avoids the troublesome normative issues that the literal interpretation raises. If states are persons, then they seem to be entitled to the same rights as human beings (Hindriks, 2014). Wendt (2004: 293) acknowledges this: 'if states really are people too, then we need some other, non-metaphysical way to justify liberalism, which may force us to confront possibly uncomfortable truths'. Distinguishing artificial persons from natural persons dissolves this problem. States and human beings are both persons, but they are different kinds of persons, so there is no reason that they must have the same rights.

Describing states as fictional artificial persons is likely to provoke objections, especially from scientific realists such as Wendt $(1999,2004)$ and Wight $(2004,2006)$. They might argue that the attributive interpretation is just the metaphorical interpretation in disguise-just a more sophisticated attempt to dismiss the state as a useful fiction. On the contrary, the claim that states are fictional persons does not imply that states are not real. Just as children are real human beings and hospitals are real objects even though they are fictional persons, states may be real institutions even though they are fictional persons. What makes a person fictional is not that it does not truly exist, but that it does 
not truly perform or authorize the actions that are attributed to it (Runciman, 2000). We could call states 'incapable' or 'passive' artificial persons to express the same point.

The attributive interpretation avoids the pitfalls of the metaphorical interpretation. First, it captures the fact that action-sentences about states are not reducible to action-sentences about individuals. 'David Cameron signed the treaty' and 'the United Kingdom signed the treaty' may both be true, and both may describe the same event, but they are not equivalent. The first sentence is agentive: it identifies David Cameron as the agent who signed the treaty. The second sentence is responsibility attributive: it identifies the United Kingdom as the owner who is responsible for the treaty. There are often many true but nonequivalent action-sentences about the same event—some about individuals, others about states; some agentive, others attributive; some authority attributive, others responsibility attributive. Which sentences we use depends on the context and on which features of the event we wish to emphasize.

Second, the attributive interpretation eliminates the need for cumbersome individualistic paraphrases. We do not need to translate 'the United Kingdom signed a treaty' into 'some members of the United Kingdom on 19 June 2012 brought it about that a treaty was signed', as Ludwig (2014) proposes. Nor do we need to list the individuals who signed the treaty, as Gilpin (1984) argues. The meaning of 'the United Kingdom signed a treaty' is already clear, as long as we recognize that the United Kingdom is a fictional artificial person rather than a natural person or a true artificial person. The intuition that animates the metaphorical interpretation - that 'the United Kingdom signed a treaty' is not akin to 'Jane signed a contract' - is correct. Where proponents of the 
metaphorical interpretation err is in trying to eliminate one type of sentence in favour of the other.

An important caveat is that the attributive interpretation is an analysis of the political language of contemporary Anglophones. It is not universal or timeless. In a society in which states were widely considered to be natural persons or true artificial persons, action-sentences about states would instead be agentive or authority attributive. This might have been the case at various times in the German-speaking world, when organic conceptions of the state prevailed. Different languages have different grammar, and different societies and times have different political concepts. Even 'the modern idea of the State as a form of public power separate from ruler and ruled', which makes possible the distinction between actions of states and actions of individuals, was not fully developed until the seventeenth century (Skinner, 1978: 352-58, at 353; 2002: 394-404). There are many other forms of political language, and these ought to be understood in their own terms.

\section{Conclusion}

Action-sentences about states are the basic currency of international relations—so basic that they have received little analysis. Although there has recently been a great deal of debate about whether states are agents, our practice of ascribing actions to states has been addressed only as an aside. Those on both sides of the state-as-agent debate have treated the question of how to interpret action-sentences about states as secondary or epiphenomenal. The aim of this article has been to shift the focus of the debate from ontology to language, to reexamine the two common interpretations of action-sentences about states, and 
to develop an alternative interpretation using Hobbes' theory of attributed action. The central argument is that action-sentences about states are responsibility attributive: they identify states as the owners of actions, not as agents, authors, or subjects of tropes.

States are not the only collective subjects of action-sentences. We also ascribe actions to corporations, unions, charities, provinces, intergovernmental organizations, rebel groups, drug cartels, the global market, and the international community. However, we should be cautious about extending the attributive interpretation from states to other types of groups. While action-sentences about corporations and intergovernmental organizations seem closely analogous to action-sentences about states, action-sentences about non-corporate groups, such as the market and the international community, differ in some ways. We often hold states and corporations responsible for their 'reckless actions', but we tend to hold particular individuals, firms, and states responsible for the reckless actions that we attribute to the market and the international community. This may be a practical difference rather than a theoretical one: the market and the international community, unlike states and corporations, have no assets to seize and no bank accounts from which to pay fines. In any case, other types of collective action-sentences may follow their own logic, which ought to be analyzed in its own right. 


\section{Acknowledgements}

I thank Duncan Bell and two anonymous reviewers for their thoughtful comments and criticisms. I am especially grateful to James Keeley, who encouraged me to write this article in the first place.

\section{Notes}

1 The main contributors to the state-as-agent debate include Wolfers (1962), Wendt (1999, 2004, 2005), Wight (1999, 2004, 2006), Jackson (2004a, 2004b), Neumann (2004), Schiff (2008), Franke and Roos (2010), Kustermans (2011), and Lomas $(2005,2014)$.

2 The IR and political science literature of Gilpin's era is peppered with similar arguments (e.g., Beitz, 1999 [1979]: 76; Bueno de Mesquita, 1981: 11-18; Easton, 1981: 361; Jessop, 1990: 366-7).

3 Wendt treats 'person', 'actor', and 'agent' as synonyms (see 1987: 338-39, 339n; 2004: 289n; 2015: 23).

${ }^{4}$ Hobbes scholars disagree about whether artificial persons are representatives or 'representees' (cf. Runciman, 2000; Skinner, 1999). Hobbes tells us the former in Chapter 16 of Leviathan but the latter in Chapter 42 of Leviathan and Chapter 15 of De Homine. I follow Copp (1980: 582-83) and Green (2015: 27) in interpreting 'artificial person' as 'that which is represented'. They point out that nothing significant turns on this choice, since we can use 'representative' to cover Hobbes' usage of 'person' in Chapter 16 of Leviathan. Any terminology will work as long as it preserves the key distinction between the entity that performs an action (the agent) and the entity to which the action is attributed (the owner). ${ }^{5}$ Hobbes (2012: 250, 252) uses 'author' and 'owner' as synonyms. Following Runciman (2000: 273), I distinguish authorship from ownership to account for the difference between commissioning an action and taking responsibility for an action. 


\section{References}

BBC (2016) India launches mini space shuttle. BBC News, May 23.

Beitz CR (1999 [1979]) Political Theory and International Relations. Princeton: Princeton University Press.

Bueno de Mesquita B (1981) The War Trap. New Haven: Yale University Press.

Carr EH (1946) The Twenty Years' Crisis 1919-1939: An Introduction to the Study of International Relations. London: Macmillan.

Cassese A (2001) International Law. Oxford: Oxford University Press.

Chalmers DJ (2002) On sense and intension. In: Tomberlin J (ed) Philosophical Perspectives 16: Language and Mind. Oxford: Blackwell, pp. 135-82.

Condorelli L and Kress K (2010) Attribution of conduct to the state: state organs and entities empowered to exercise elements of governmental authority. In Crawford J, Pellett A, Olleson S, and Parlett K (eds) The Law of International Responsibility. Oxford: Oxford University Press, 221-36.

Copp D (1979) Collective actions and secondary actions. American Philosophical Quarterly 16(3): 177-86.

Copp D (1980) Hobbes on artificial persons and collective actions. The Philosophical Review 89(4): 579-606.

Copp D (2006) On the agency of certain collective entities: An argument from 'normative autonomy'. Midwest Studies in Philosophy 30(1): 194-221.

Crawford J (2013) State Responsibility: The General Part. New York: Cambridge University Press.

Cruse DA (1986) Lexical Semantics. Cambridge: Cambridge University Press.

Easton D (1981) The political system besieged by the state. Political Theory 9(3): 303-25.

Erskine T (2001) Assigning responsibilities to institutional moral agents: The case of states and quasi-states. Ethics \& International Affairs 15(2): 67-85.

Finnemore M (2003) The Purpose of Intervention: Changing Beliefs about the Use of Force. Ithaca: Cornell University Press.

Franke U and Roos U (2010) Actor, structure, process: Transcending the state personhood debate by means of a pragmatist ontological model for International Relations theory. Review of International Studies 36(4): 1057-77. 
French PA (1984) Collective and Corporate Responsibility. New York: Columbia University Press.

Gilpin RG (1984) The richness of the tradition of political realism. International Organization 38(2): 287-304.

Gould HD (2009) International criminal bodies. Review of International Studies 35(3): 701-21.

Green MJ (2015). Authorization and political authority in Hobbes. Journal of the History of Philosophy 53(1): 25-47.

Hindriks F (2014) How autonomous are collective agents? Corporate rights and normative individualism. Erkenntis 79(9): 1565-85.

Hobbes T (1991) On Man [De Homine], Wood CT, Scott-Craig TSK and Gert B (trans). In: Gert B (ed) Man and Citizen. Indianapolis: Hackett.

Hobbes T (1998) On the Citizen [De Cive], Tuck R and Silverthorne M (trans). New York: Cambridge University Press.

Hobbes T (2012) Leviathan, Malcolm N (ed). Oxford: Oxford University Press.

International Law Commission (2001) Articles on Responsibility of States for Internationally Wrongful Acts. New York: United Nations.

Jackson PT (2004a) Forum introduction: Is the state a person? Why should we care? Review of International Studies 30(2): 225-58.

Jackson PT (2004b) Hegel's house, or 'people are states too'. Review of International Studies 30(2): 281-87.

Jessop B (1990) State Theory: Putting Capitalist States in their Place. University Park, PA: Pennsylvania State University Press.

Keeley JF (2007) To the Pacific? Alexander Wendt as explorer. Millennium: Journal of International Studies 35(2): 417-30.

Kustermans J (2011) The state as citizen: state personhood and ideology. Journal of International Relations and Development 14(1): 1-27

Lang AF Jr (2007) Crime and punishment: Holding states accountable. Ethics \& International Affairs 21(2): 239-57.

List C and Pettit P (2006) Group agency and supervenience. The Southern Journal of Philosophy 44(S1): 85-105. 
List C and Pettit P (2011) Group Agency: The Possibility, Design, and Status Corporate Agents. New York: Oxford University Press.

Lomas P (2005). Anthropomorphism, personification and ethics: A reply to Alexander Wendt. Review of International Studies 31(2): 349-55.

Lomas P (2014) Unnatural States: The International System and the Power to Change. New Brunswick, NJ: Transaction.

Lover R (2008) Elementary Logic. London: Springer-Verlag.

Ludwig K (2007) Collective intentional behaviour from the standpoint of semantics. Noûs 41(3): 355-93.

Ludwig, K (2014) The ontology of collective action. In: Chant SR, Hindriks F and Preyer G (eds) From Individual to Collective Intentionality: New Essays. New York: Oxford University Press, pp. 112-33.

Marks MP (2011) Metaphors in International Relations Theory. New York: Palgrave Macmillan.

Neumann IB (2004) Beware of organicism: The narrative self of the state. Review of International Studies 30(2): 259-67.

Nollkaemper A (2003) Concurrence between individual responsibility and state responsibility in international law. International and Comparative Law Quarterly 52(3): 615-40.

Nuremberg International Military Tribunal (1947) Judgment. Reprinted in the American Journal of International Law 41(1): 172-333.

Pasternak A (2013) Limiting states' corporate responsibility. Journal of Political Philosophy 21(4): 361-81.

Pettit P (2008) Made with Words: Hobbes on Language, Mind, and Politics. Princeton: Princeton University Press.

Pettit P (2014) Group agents are not expressive, pragmatic or theoretical fictions. Erkenntnis 79(s9): 1641-62.

Quine WVO (1948) On what there is. Review of Metaphysics 2(5): 21-38.

Reuters (2016) British banker behind firm sanctioned over North Korea nuclear programme - Guardian. Reuters UK, April 6.

Ringmar E (1996) On the ontological status of the state. European Journal of International Relations 2(4): 439-66. 
Runciman D (2000) What kind of person is Hobbes's state? A reply to Skinner. Journal of Political Philosophy 8(2): 268-78.

Runciman D (2009) Hobbes' theory of representation: Anti-democratic or protodemocratic? In: Shapiro I et al. (eds) Political Representation. Cambridge: Cambridge University Press, pp. 15-34.

Schiff J (2008) 'Real'? As if! Critical reflections on state personhood. Review of International Studies 34(2): 363-77.

Sheehy P (2016) The Reality of Social Groups. New York: Routledge.

Shepsle KA (1992) Congress is a 'they', not an 'it': Legislative intent as oxymoron. International Review of Law and Economics 12(2): 239-56.

Skinner Q (1978) The Foundations of Modern Political Thought Volume Two: The Age of Reformation. Cambridge: Cambridge University Press.

Skinner Q (1999) Hobbes and the purely artificial person of the state. Journal of Political Philosophy 7(1): 1-29.

Skinner Q (2002) Vision of Politics Volume 2: Renaissance Virtues. Cambridge: Cambridge University Press.

Skinner Q (2007) Hobbes on person, authors and representatives. In: Springborg P (ed) The Cambridge Companion to Hobbes's Leviathan. Cambridge: Cambridge University Press.

Stilz A (2011) Collective responsibility and the state. Journal of Political Philosophy 19(2): 190-208.

Tollefsen DP (2015) Groups as Agents. Cambridge: Polity.

Valentini L (2011) Justice in a Globalized World: A Normative Framework. New York: Oxford University Press.

Waltz KN (1979) Theory of International Politics. New York: McGraw-Hill.

Wendt A (1987) The agent-structure problem in international relations theory. International Organization 41(3): 335-70.

Wendt A (1999) Social Theory of International Politics. New York: Cambridge.

Wendt A (2004) The state as person in international theory. Review of International Studies 30(2): 289-316.

Wendt A (2005) How not to argue against state personhood: A reply to Lomas. Review of International Studies 31(2): 357-60. 
Wendt A (2015) Quantum Mind and Social Science: Unifying Physical and Social Ontology. Cambridge: Cambridge University Press.

Wight C (1999) They shoot dead horses don't they? Locating agency in the agentstructure problematique. European Journal of International Relations 5(1): 109-42.

Wight C (2004) State agency: Social action without human activity? Review of International Studies 30(2): 269-80.

Wight C (2006) Agents, Structures and International Relations: Politics as Ontology. New York: Cambridge University Press.

Wolfers A (1962) The actors in international politics. In: Wolfers F (ed) Discord and Collaboration: Essays on International Politics. Baltimore: John Hopkins Press, pp. 3-24.

Yaqub AM (2013) An Introduction to Logical Theory. Peterborough, ON: Broadview. 